\title{
DIVERSITY AND STABILITY OF FISHES (TELEOSTEI) IN A TEMPORARY RIVER OF THE BRAZILIAN SEMIARID REGION
}

\author{
Elvio S.F. Medeiros ${ }^{1}$ \\ Leonardo Maltchik ${ }^{2}$
}

\begin{abstract}
The effects of hydrological disturbances by flooding and drought on the diversity and stability in a temporary river fish community in the Brazilian semiarid region were analyzed over the 1996 hydrological cycle. Twelve collections of fishes were made during the wet and dry phases, and 789 individuals of 16 species were collected. Diversity was measured using Simpson's Index (S) and community stability was analyzed by the variation in abundance using Kendall's W concordance test. Fish diversity in the Taperoá river was subjected to hydrological disturbances by flooding and drought. During the wet phase the diversity was higher $(S=0.855)$ than during the dry phase $(\mathrm{S}=0.771)$. The community was considered stable during the whole annual hydrological cycle $(\mathrm{W}=$ $0.418 \mathrm{p}<0.001$ ), but a higher stability in the community was found during the dry phase. During the dry phase the number of dominant species was smaller than during the wet phase.
\end{abstract}

KEYWORDS. Teleostei, intermittent stream, disturbance, diversity, stability.

\section{INTRODUCTION}

Measures of stability are designed to give information about the behaviour of systems subjected to various sorts of disturbances (PIANKA, 1994). Disturbance is thought to play an important role in the structure of communities of stream fishes (KARR \& Freemark, 1985; Resh et al., 1988; Poff \& Ward, 1990). Intermittent stream fish communities exposed to disturbance caused by floods and drought have to persist in these environments which are characterized by fluctuating flows (MefFE \& MinCKLEY, 1987). Numerous different concepts of stability have been applied to populations and communities, and the debate regarding stability of stream fish fauna or local assemblages is not new (Pianka, 1994; Matthews, 1998). MefFe \& Minckley (1987) define stability

\footnotetext{
1. Griffith University, Australian School of Environmental Studies, Faculty of Environmental Sciences, CCISR, Nathan Campus, Brisbane, QLD 4111, Australia.

2. Universidade do Vale do Rio dos Sinos - UNISINOS, Centro II, Av. Unisinos, 950, 93022-000, São Leopoldo, Rio Grande do Sul, Brasil. (maltchik@ cirrus.unisinos.br)
} 
as the relative constancy of the abundance of species over a period of time in spite of disturbance, and this may result from resistance, when relative species abundance is unchanged despite potentially disruptive forces, or from resilience, the rapid return to a former state following a disturbance.

Streams of the Brazilian semiarid region are characterized by extremes of flood and drought (Maltchiк, 1996a; b), but the effects of these disturbance agents on the stream fish fauna are poorly understood (Medeiros \& MaLtchiK, 1997; 1998; 1999). The aims are to analyze the effects of hydrological disturbances (flood and drought) on the stability and diversity of fishes of a temporary river from the Brazilian semiarid region over a hydrological cycle.

\section{MATERIAL AND METHODS}

The study was conducted in the Taperoá river system $\left(432 \mathrm{~km}^{2}\right.$ in area) located in the Brazilian semiarid region. Sampling was conducted in a medium reach ( $7^{\circ} 23^{\prime} 14^{\prime \prime}$ S, 36 $33^{\prime} 24^{\prime \prime}$ W) of the Taperoá river, a sixthorder (STRAHLER, 1964) temporary tributary of the Paraíba river (fig. 1). The Taperoá river is about $133 \mathrm{~km}$ in length, flowing from Cariris Hill, in the Teixeira municipality, at $720 \mathrm{~m}$ above sea-level and dropping to $425 \mathrm{~m}$ where it joins the Paraíba river by means of the Epitácio Pessoa reservoir. The stream is underlain by an extensive alluvium deposit (up to $10 \mathrm{~m}$ deep in some reaches) which allows an exchange of surface and subsurface waters, and is underlain by crystaline rock, lacking groundwater aquifers. The stream bottom is usually composed of sand, but gravel substrate and granitic extrusions may be found in some reaches. The natural vegetation in the basin, denominated "Caatinga", is characterized by an arboreal to shrubby deciduous open forest composed of xerophytic species, such as "mandacaru" Cereus jamacaru DC. (Cactaceae), "facheiro" Pilosocereus piauhiensis (Guerke) Byl. \& Rowl. (Cactaceae), "xique-xique" Pilosocereus gounellei (Weber) Byl. \& Rowl. (Cactaceae), "quipá" Opuntia inamoena K. Schum. (Cactaceae), "catingueira" Caesalpinia pyramidalis Tul. (Leguminosae), "pereiro" Aspidosperma pyrifolium Mart. (Apocynaceae) and "macambira" Bromelia laciniosa Mart. \& Schult. (Bromeliaceae). The marginal stream vegetation has been modified by the planting of the Leguminosae "algaroba" tree (Prosopis algarobilla G. Riseb.).

Thirteen fish collections were made during the different hydrological phases (wet and dry) of an annual hydrological cycle, from February to August 1996 (there were no surface water during the rest of the year). Fishes were collected with different sorts of seine, cast and gill nets with different meshes (7.0, 5.0, 3.0, 1.0 and $0.5 \mathrm{~cm}$ between knots). Gill net span ranged from 10 to $25 \mathrm{~m}$ with height of $1.5 \mathrm{~m}$. During the period of continuous surface flow, diurnal and nocturnal samplings were carried out in shallow and deep riffles and pools along a $300 \mathrm{~m}$ reach. During discontinuous surface flow, diurnal and nocturnal samplings were taken in the remaining pools formed along the same $300 \mathrm{~m}$ reach. The time established for collection during both wet and dry phases was about 3 hours, in order to standardize the collections. Samplings during the flood period were homogeneous throughout the various habitats (different edges, depths and widths of the stream). During the dry period samplings were taken in different pool areas, such as edges, upper and lower ends and mid-areas. Samples of collected fishes are included at the Ichthyological Collection of the Universidade Federal da Paraíba (specimens UFPB 3656 to UFPB 3672).

Species richness per collection was measured according to ODUM (1988), corresponding to the relationship between the number of species and the number of individuals. Species diversity (S) was calculated for each hydrological phase and for each collection using Simpson's diversity index. Dominance was measured as the percentual of the relation between the amount of individuals of a species in a collection and the sum of all the individuals of that collection. Maximum species dominance was the highest percentual value of dominance for each collection.

To determine the variability of fish populations, the Coefficient of Variation (standard deviation divided by the mean abundance for each species) of the estimated population size for each species was used. As the Coefficient of Variation (CV) separates an assemblage or community into its component populations (Grossman et al., 1990), the $\mathrm{CV}$ was calculated for each species for detecting differences among species and their variation in samples over the time. The CV values were examined and interpreted based on the criteria described by MaTTHEwS (1998).

The level of stability of species was tested by the concordance of relative abundance rankings over each hydrological phase during the entire study period. Relative abundance of fishes was ranked and evaluated for collection-to-collection concordance using Kendall's W (CONOVER, 1971), a non-parametric measurement that 


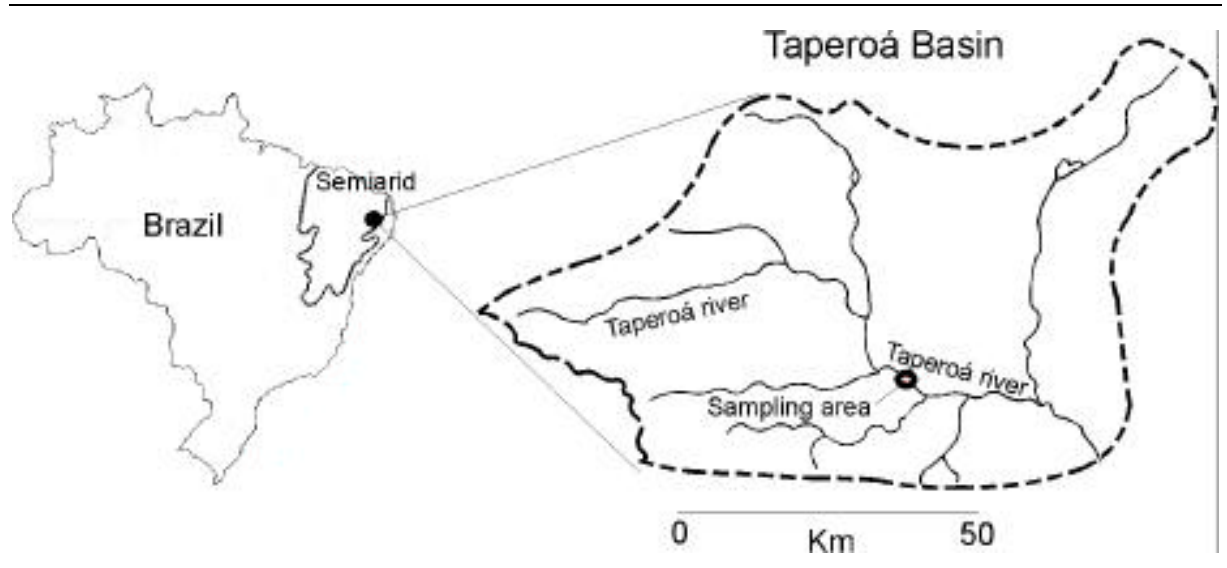

Fig. 1. Position of the Taperoá River basin in Brazilian semiarid region and sampling area ( $7^{\circ} 23^{\prime} 14^{\prime \prime}$ ' S, 36 33' $24^{\prime}$, W) in Taperoá river, State of Paraiba, Brazil.

tests for overall concordance among multiple samples under the null hypothesis of randomness. According to MefFE \& MinCKLEY (1987) the absence of concordance supports the view of a non-stable community and the presence of concordance suggests approximation to a stable state. In this way, a community near the equilibrium would have more constant rankings of its constituent species than a would fluctuating one.

\section{RESULTS}

During the period studied the mean air temperature was over $25,7^{\circ} \mathrm{C}$, ranging between $14{ }^{\circ} \mathrm{C}$ to $36{ }^{\circ} \mathrm{C}$. Total rainfall in this period was $426 \mathrm{~mm}$. The unpredictability of rainfall, its frequency, and the small drainage basin area determined the temporary nature of the Taperoá river. During the dry period some surface water remained in pools which usually have subsurface connectivity during the beginning of the dry phase.

In 1996 the Taperoá river was characterized by two different hydrological phases: (1) the wet phase, with a continuous 3-month surface water flow and (2) the dry phase, when surface flow ceased and some isolated pools remained in the main channel (tab. I). During the wet phase the river presented two spates in surface water flow. The first spate (discharge $=7.00 \mathrm{~m}^{3} / \mathrm{s}$ ) iniciated the wet phase (March 06) and the second one (discharge $=1.21 \mathrm{~m}^{3} / \mathrm{s}$ ) occurred in the middle of the wet phase (April 19) (tab. I). During the dry phase one of the pools studied did not dry up. This pool presented about $600 \mathrm{~m}^{2}$ in area and $3 \mathrm{~m}$ depth at the deepest point.

During the 1996 hydrological cycle, 789 individuals of 16 species and 9 families were collected $(S=0.846$ ) (tab. II). Species richness did not present a significant variation between wet and dry phases (Mann-Whitney $\mathrm{U}=12.0$; $\mathrm{CV}=0.401$ ). Otherwise, this feature presented low oscillation at the beginning of the wet phase $(\mathrm{CV}=0.310)$. The highest values of richness were found during the second spate and at the end of the wet phase a decrease in richness was observed (fig. 2). At the beginning of the dry phase, richness values increased progressively, dropping down at the end of this phase $(\mathrm{CV}=$ $0.646)$. 
Table I. Physical and chemical characteristics of the Taperoá River during the 1996 hydrological cycle (* area of one of the pools which dried up in the Taperoá river bed; nd, not detected; - parameter absent).

\begin{tabular}{cccccc}
\hline $\begin{array}{c}\text { Sampling } \\
\text { Date }\end{array}$ & $\begin{array}{c}\text { Hydrological } \\
\text { Phase }\end{array}$ & $\begin{array}{c}\text { Discharge } \\
\left(\mathrm{m}^{3} / \mathrm{s}\right)\end{array}$ & $\begin{array}{c}\text { Water Vel. } \\
(\mathrm{m} / \mathrm{s})\end{array}$ & $\begin{array}{c}\text { Depth } \\
(\mathrm{cm})\end{array}$ & $\begin{array}{c}\text { Pool Area } \\
\left(\mathrm{m}^{2}\right)^{*}\end{array}$ \\
\hline $28 \mathrm{Feb}$ & - & - & - & - & - \\
$06 \mathrm{Mar}$ & wet & 7.00 & 0.85 & 45.0 & - \\
$13 \mathrm{Mar}$ & wet & 4.00 & 0.58 & 33.5 & - \\
$21 \mathrm{Mar}$ & wet & 2.25 & 0.57 & 18.9 & - \\
$29 \mathrm{Mar}$ & wet & 1.02 & 0.54 & 12.7 & - \\
13 Apr & wet & 0.97 & 0.55 & 9.8 & - \\
19 Apr & wet & 1.21 & 0.44 & 14.7 & - \\
03 May & wet & 1.06 & 0.55 & 10.7 & - \\
24 May & wet & 0.03 & 0.28 & 2.6 & - \\
07 Jun & wet & nd & nd & 1.5 & 11.7 \\
26 Jul & dry & - & - & 9.3 & 2.0 \\
22 Aug & dry & - & - & 1.5 & 1.0 \\
\hline
\end{tabular}

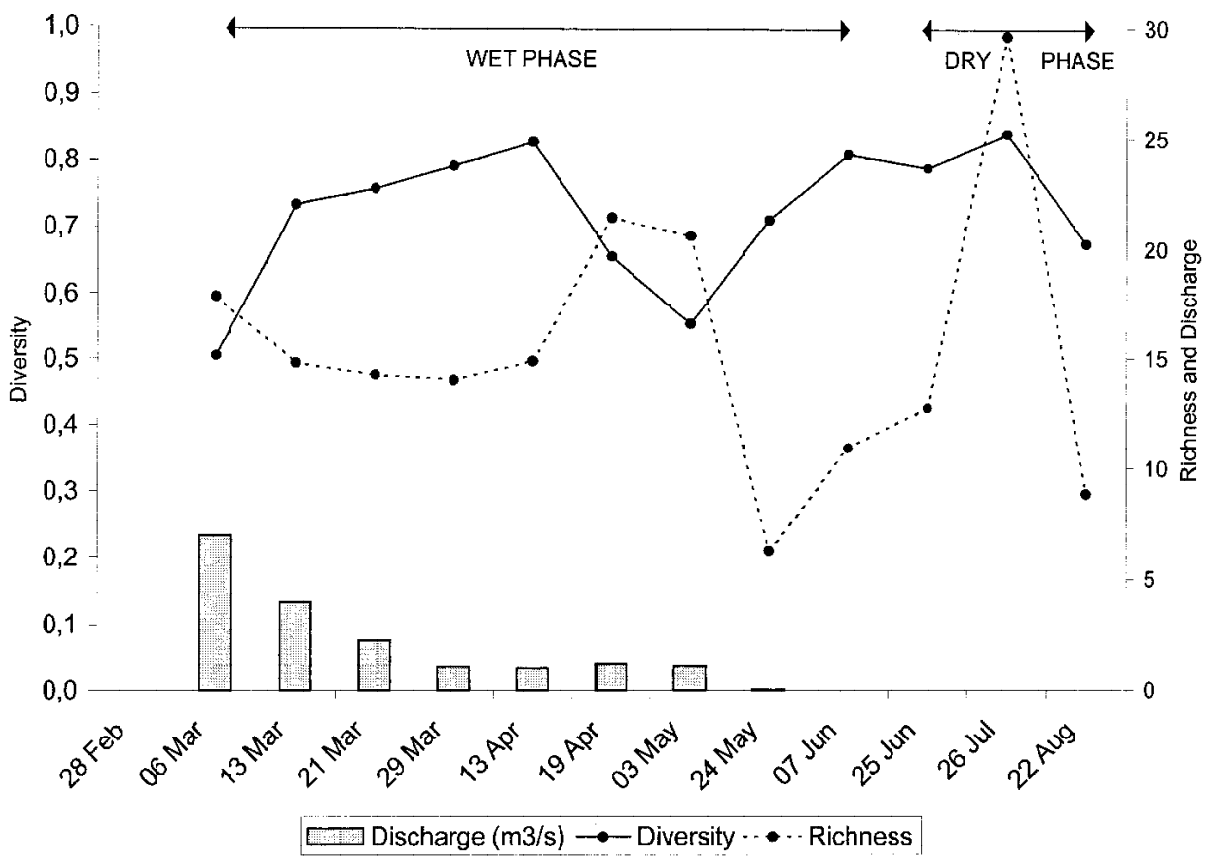

Fig. 2. Diversity and richness of fishes in Taperoá River during the 1996 hidrological cycle. 
Table II. Checklist and catalogue number (UFPB, Ichthyological Collection of the Universidade Federal da Paraíba) of fish species found in the Taperoá River during the 1996 hydrological cycle, listed according to the classification of NELSON (1994).

\begin{tabular}{|c|c|}
\hline UFPB & Species \\
\hline & Teleostei \\
\hline & Characiformes \\
\hline & Hemiodontidae \\
\hline & Parodontinae \\
\hline \multirow[t]{3}{*}{3664} & Apareiodon davisi (Fowler, 1941) \\
\hline & Curimatidae \\
\hline & Curimatinae \\
\hline 3669 & Steindachnerina notonota (Miranda-Ribeiro, 1937) \\
\hline \multirow[t]{2}{*}{3670} & Psectrogaster rhomboides (Eigenmann \& Eigenmann, 1889) \\
\hline & Prochilodontinae \\
\hline \multirow[t]{3}{*}{3660} & Prochilodus brevis Steindachner, 1874 \\
\hline & Anostomidae \\
\hline & Anostominae \\
\hline \multirow[t]{2}{*}{3665} & Leporinus piau Fowler, 1941 \\
\hline & Erythrinidae \\
\hline \multirow[t]{2}{*}{3659} & Hoplias aff. malabaricus (Bloch, 1794) \\
\hline & Characidae \\
\hline \multirow[t]{2}{*}{3657} & Triportheus signatus (Garman, 1890) \\
\hline & Tetragonopterinae \\
\hline 3668 & Astyanax aff. bimaculatus (Linnaeus, 1758) \\
\hline \multirow[t]{2}{*}{3656} & Astyanax aff. fasciatus (Cuvier, 1819) \\
\hline & Auchenipteridae \\
\hline \multirow[t]{3}{*}{3667} & Parauchenipterus cratensis (Ribeiro, 1973) \\
\hline & Loricariidae \\
\hline & Hypostominae \\
\hline \multirow[t]{4}{*}{3661} & Hypostomus sp. \\
\hline & Cyprinodontiformes \\
\hline & Poeciliidae \\
\hline & Poeciliinae \\
\hline \multirow[t]{3}{*}{3672} & Poecilia reticulata (Peters, 1859) \\
\hline & Perciformes \\
\hline & Cichlidae \\
\hline 3658 & Geophagus brasiliensis (Quoy \& Gaimard, 1824) \\
\hline 3666 & Cichlassoma orientale Kullander, 1983 \\
\hline 3662 & Oreochromis niloticus (Linnaeus, 1758) \\
\hline 3663 & Crenicichla menezesi Ploeg, 1991 \\
\hline
\end{tabular}

Fish diversity was higher during the wet phase than during the dry phase (fig. 2). During the wet phase the number of species per collection ranged from 4 to $14(\mathrm{CV}=$ $0.391 ; \mathrm{S}=0.855$ ) and during the dry phase the number of species per collection ranged from 8 to $11(\mathrm{CV}=0.158 ; \mathrm{S}=0.771)$. The amplitude of the values of diversity was higher during the wet phase $(\mathrm{S}=0.505-0.828 ; \mathrm{CV}=0.160)$ than the dry phase $(\mathrm{S}=$ $0.675-0.840 ; \mathrm{CV}=0.110$ ). During the spates, fish diversity values were low, and as the surface water flow decreased the diversity increased.

None of the species found at the Taperoá river remained dominant throughout the annual cycle studied. Hypostomus sp., Astyanax aff. bimaculatus and Psectrogaster rhomboides were the species with the highest values of dominance. The values of 


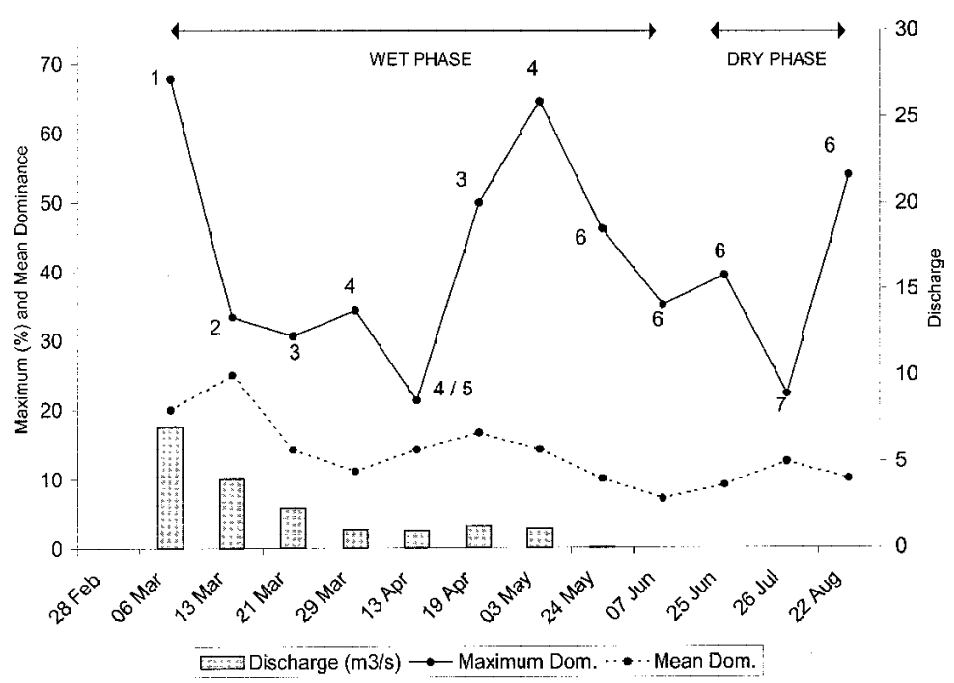

Fig. 3. Maximum dominance (\%) and mean dominance values with the correspondent fish species in the Taperoá River during the 1996 hydrological cycle. 1, Astyanax aff. fasciatus; 2, Prochilodus brevis; 3, Psectrogaster rhomboides; 4, Astyanax aff. bimaculatus; 5, Leporinus piau; 6, Hypostomus sp; 7, Oreochromis niloticus.

maximum dominance $(\mathrm{CV}=0.366)$ of the fish species was found in the Taperoá river during the studied hydrological cycle (fig. 3). Maximum dominance of species was negatively correlated with species diversity (Spearman $p=-0.87 p<0.001$ ). During the wet phase more fish species presented high values of maximum dominance than during the dry phase. The two species of the genus Astyanax presented the highest values of maximum dominance. During the wet phase five species presented high values of maximum dominance (Prochilodus brevis, Psectrogaster rhomboides, Hypostomus sp., Oreochromis niloticus and Leporinus piau), and most of them are classified as migratory species (Prochilodus brevis, Psectrogaster rhomboides and Leporinus piau). The nonmigratory species (Oreochromis niloticus and Hypostomus sp.) presented the highest values of maximum dominance at the end of the wet phase and during the dry phase.

The most common species during the hydrological cycle studied was Astyanax aff. bimaculatus, which was present in both hydrological phases and at all collections. Three other species (Triportheus signatus, Poecilia reticulata and Geophagus brasiliensis) were present only during the wet phase, and $A$. davisi was present only during the dry phase. The remaining 11 species were present in both, wet and dry phases, but they were not present in all collections.

Species more frequently present, with higher dominance and more abundant, had low values of $\mathrm{CV}$ of relative abundance. Despite this lower variation in the relative abundance showed by some species, all fish species found in the studied river were classified as highly fluctuating (according to the criteria described by MATTHEws, 1998), showing a general absence of stability presented by individual fish species (tab. III).

The abundance per collection did not present significant variation between hydrological phases (Mann-Whitney $\mathrm{U}=12.5 ; \mathrm{CV}=0.688$ ), and the relative abundance rankings were concordant over all the collections during the whole hydrological cycle 
Table III. Values of presence $(\%)$, dominance $(\%)$, mean abundance and coefficient of variation $(\mathrm{CV})$ of abundance per species in the Taperoá River during the 1996 hydrological cycle.

\begin{tabular}{lcccc}
\hline \multicolumn{1}{c}{ Species } & $\begin{array}{c}\text { Presence } \\
(\%)\end{array}$ & $\begin{array}{c}\text { Dominance } \\
(\%)\end{array}$ & $\begin{array}{c}\text { Mean } \\
\text { Abundance }\end{array}$ & $\begin{array}{c}\text { CV of } \\
\text { Abundance }\end{array}$ \\
\hline Astyanax aff. bimaculatus & 100.0 & 16.9 & 11.1 & 0.845 \\
Leporinus piau & 83.3 & 4.9 & 3.3 & 1.011 \\
Prochilodus brevis & 83.3 & 5.1 & 3.3 & 1.192 \\
Psectrogaster rhomboides & 75.0 & 15.2 & 10.0 & 1.082 \\
Hypostomus sp. & 66.7 & 28.8 & 18.9 & 1.177 \\
Astyanax aff. fasciatus & 66.7 & 6.7 & 4.4 & 1.923 \\
Triportheus signatus & 58.3 & 4.8 & 3.2 & 1.539 \\
Hoplias aff. malabaricus & 58.3 & 6.7 & 4.4 & 1.022 \\
Steindachnerina notonota & 50.0 & 3.7 & 2.4 & 1.869 \\
Oreochromis niloticus & 50.0 & 3.2 & 2.1 & 1.792 \\
Cichlassoma orientale & 41.7 & 2.2 & 1.4 & 1.809 \\
Crenicichla menezesi & 25.0 & 0.6 & 0.4 & 2.085 \\
Parauchenipterus cratensis & 25.0 & 0.5 & 0.3 & 2.150 \\
Poecilia reticulata & 16.7 & 0.5 & 0.3 & 2.351 \\
Apareiodon davisi & 8.3 & 0.1 & 0.1 & 3.464 \\
Geophagus brasiliensis & 8.3 & 0.1 & 0.1 & 3.464 \\
\hline
\end{tabular}

Table IV. Values of abundance of species per collection in the Taperoá River during the 1996 hydrological cycle.

\begin{tabular}{lcccccccccccccc}
\hline \multicolumn{1}{c}{ Species } & 28 & 06 & 13 & 21 & 29 & 13 & 19 & 03 & 24 & 07 & 25 & 26 & 22 & Total \\
& Feb & Mar & Mar & Mar & Mar & Apr & Apr & May & May & Jun & Jun & Jul & Aug & \\
\hline A. aff. bimaculatus & 0 & 3 & 5 & 13 & 22 & 10 & 1 & 22 & 25 & 13 & 4 & 5 & 10 & 133 \\
A. aff. fasciatus & 0 & 19 & 5 & 0 & 12 & 0 & 0 & 0 & 7 & 5 & 1 & 1 & 3 & 53 \\
H. aff. malabaricus & 0 & 0 & 0 & 1 & 0 & 6 & 0 & 3 & 10 & 12 & 9 & 0 & 12 & 53 \\
Hypostomus sp. & 0 & 0 & 0 & 1 & 0 & 9 & 0 & 1 & 73 & 45 & 34 & 3 & 61 & 227 \\
O. niloticus & 0 & 0 & 0 & 0 & 1 & 0 & 0 & 1 & 0 & 6 & 4 & 6 & 7 & 25 \\
A. davisi & 0 & 0 & 0 & 0 & 0 & 0 & 0 & 0 & 0 & 0 & 0 & 1 & 0 & 1 \\
C. orientale & 0 & 0 & 0 & 0 & 2 & 0 & 0 & 0 & 0 & 3 & 5 & 4 & 3 & 17 \\
C. menezesi & 0 & 0 & 0 & 0 & 0 & 0 & 1 & 0 & 0 & 1 & 3 & 0 & 0 & 5 \\
G. brasiliensis & 0 & 0 & 0 & 0 & 0 & 0 & 0 & 0 & 0 & 1 & 0 & 0 & 0 & 1 \\
P. cratensis & 0 & 1 & 0 & 0 & 0 & 0 & 0 & 0 & 2 & 0 & 1 & 0 & 0 & 4 \\
P. reticulata & 0 & 0 & 0 & 0 & 0 & 0 & 0 & 0 & 2 & 2 & 0 & 0 & 0 & 4 \\
T. signatus & 0 & 0 & 0 & 13 & 4 & 6 & 8 & 1 & 4 & 2 & 0 & 0 & 0 & 38 \\
S. notonota & 0 & 0 & 8 & 0 & 13 & 0 & 0 & 0 & 1 & 2 & 0 & 2 & 3 & 29 \\
P. brevis & 0 & 1 & 9 & 3 & 3 & 5 & 2 & 0 & 0 & 6 & 5 & 5 & 1 & 40 \\
L. piau & 0 & 4 & 0 & 3 & 3 & 10 & 2 & 2 & 1 & 5 & 6 & 0 & 3 & 39 \\
P. rhomboides & 0 & 0 & 0 & 15 & 4 & 1 & 14 & 4 & 33 & 25 & 14 & 0 & 10 & 120 \\
\hline Total & 0 & 28 & 27 & 49 & 64 & 47 & 28 & 34 & 158 & 128 & 86 & 27 & 113 & 789 \\
\hline
\end{tabular}

$(\mathrm{W}=0.418 ; \mathrm{p}<0.001)(\mathrm{tab}$. IV). Fish species ranking for relative abundance per collection was significantly concordant during both wet $(\mathrm{W}=0.473 \mathrm{p}<0.001$; $\mathrm{CV}=$ $0.764)$ and dry $(\mathrm{W}=0.643 \mathrm{p}=0.016 ; \mathrm{CV}=0.584)$ phases, indicating the existence of stability in the community of fishes from the Taperoá river throughout the year. Thus, the null hypothesis, of non-concordance among fish species abundance rankings was rejected, indicating that the abundance ranking tested was stable over these two periods. 
In addition, the higher value of $\mathrm{W}$ during the dry phase is an indication that the community was stabler during this phase than during the wet phase.

\section{DISCUSSION}

Intermittent streams and rivers from the Brazilian semiarid region support low diversified fish communities, with about 15 to 20 species in each river or stream (PAIVA, 1978). Although these numbers have been increasing with more recent surveys, PAIVA (1978) mentioned nearly 50 fish species within the aquatic ecosystems of the Brazilian semiarid region. The number of fish species found in the Taperoá river is in accordance with these figures, and this number is low in comparison with perennial systems of other non-arid basins (Menezes, 1970; Lowe-McConnell, 1975; Paiva, 1978). The number of species found in the Taperoá river may be related to the temporary regime of this river and its hierarchical level, which provide a longer water flow period than other ephemeral streams of the Brazilian semiarid region. Fish diversity of the Taperoá river was subjected to hydrological disturbances by flooding and drought, and these two events were important agents affecting the diversity and the stability of the river fish community. During the wet phase, between the two spates of the surface water flow and after the second spate, fish diversity increased while the dominance of species decreased.

According to MAY (1974) and WINTERHALDER (1980) spatial heterogeneity is important to the maintenance of stability and diversity in communities subjected to the disruptive power of disturbances. At the Taperoá river, the diversity of fish progressively increased as the surface water flow decreased. It was during the period with surface water flow that the spatial heterogeneity was higher in the Taperoá river. During the period with moderated water flow occurred a marked distinction among the different kinds of habitats (riffles, pools, deeper and shallow areas). The capacity of the river to connect different freshwater ecosystems allowed the dispersion and subsequent input of many different fish species coming from other semiarid habitats, such as permanent pools and dams, increasing fish diversity. Despite the presence of other species during the wet phase, the number of dominant species and the values of dominance were low. During the dry phase, the absence of water flow caused a low diversity of species and the increase of the dominance of the non-migratory species. During the dry period, the habitat became harsh and restricted (MedeIros \& MALTCHIK, 1999), and the input of other species or individuals was reduced.

Floods are one of the most important agents affecting the stability of communities due to their rapid and disruptive effects on the different groups of organisms (MEFFE \& MinCKLEY, 1987). The fish community of the Taperoá river was greatly affected by flooding. During the wet phase the species composition and diversity per collection were more variable and the stability of the community of fishes was lower than during the dry phase. The lower stability of the fish community of the Taperoá river during the wet phase was related to the occurence of flooding. Although each species presented a high level of variability in the relative abundance during the annual cycle, there was a general stability in the community during the studied period. This stability of the abundance of the fish community during the whole period allowed the persistence of the community to the former disruptive event during the wet phase. Thus, the fish community was able to resist the disruptive event during the wet phase, and increased 
its stability during the dry phase. The dry phase was characterized by the presence of pools formed in the river bed, which may represent a restricted and harsh habitat for the fish species, which could lead to changes in the structure of the community (MEDEIROS \& Maltchiк, 1999). The higher stability observed during the dry phase may be related to the presence of a large permanent pool in the Taperoá river bed, during the annual cycle studied, which represented a shelter for many individuals and species during the dry phase.

Despite the fact that intermittent streams and rivers from the Brazilian semiarid region have low fish diversity, hydrological disturbances can create new habitats in which exclusion by competition is avoided by fish species, allowing the coexistence of species which would be unable to coexist in a non-disturbed condition. Consequently, floods are able to hinder the establishment of dominant species leading to an increase in diversity. Also, the spatial heterogeneity and the presence of different hydrological phases (temporal variability), and the environmental variations within these phases are important factors in the maintenance and/or increase in the diversity of fishes.

Acknowledgments. To Dr. Ricardo Rosa, Dra. Ierecê de Lucena Rosa, and MSc Gildo Gomes Filho (Universidade Federal da Paraiba) for identifying fish species. The research was supported by CNPq (523706/952) and FINEP (1919-95) and performed at Dep. Sistemática e Ecologia (Universidade Federal da Paraíba).

\section{REFERENCES}

Conover, W. J. 1971. Practical nonparametric statistics. New York, John Wiley \& Sons. 462p.

Grossman, G. D.; Dowd, J.F. \& Crawford, M. 1990. Assemblage stability in stream fishes: a review. Environ. Manag., Dordrecht, 14: 661-671.

KARR, J.V. \& FreEMARK, K.E. 1985. Disturbance and vertebrates: an integrative perspective. In: PICKETT, S.T.A. \& White, P. S. eds. The Ecology of Natural Disturbance and Patch Dynamics. New York, Academic. p. 154-168.

Lowe-McConnell, R. H. 1975. Fish communities in tropical freshwaters. London, Longman. 337p.

MaltchiK, L. 1996a. Nossos rios temporários, desconhecidos mas essenciais. Ciência Hoje, Rio de Janeiro, 21 (122): 64-65.

1996b. Perturbação hidrológica e zona hiporreica: Conceitos básicos para pesquisas nos rios temporários do semi-árido brasileiro. Revta nordest. Biol., João Pessoa, 11 (1): 1-13.

Matthews, W. J. 1998. Patterns in freshwater fish ecology. New York, Chapman \& Hall. 756p.

MAY, R.M. 1974. Ecosystem patterns in randomly flutuating environments. Progr. Theoret. Biol., San Diego, 3: $1-50$.

Medeiros, E. S. F. \& Maltchik, L. 1997. Parasita ataca peixes nos rios do semi-árido. Ciência Hoje, Rio de Janeiro, 22 (130): 66-67.

. 1998. Implications of hydrological extremes in fish reproductive period in a temporary river of brazilian semiarid (Taperoá, PB). In: Simpósio de Ecossistemas Brasileiros, 4º Águas de Lindoia, 1998. Anais ... São Paulo, Aciesp. v. 2. p. 329-339.

1999. The effects of hydrological disturbance on the intensity of infestation of Lernaea cyprinacea in an intermittent stream fish community. J. Arid Environ., Cambridge, 43: 351-356.

MefFe, G. K. \& Minckley, W. L. 1987. Persistence and stability of fish and invertebrate assemblages in a repeatedly disturbed sonoran desert stream. Am. Midl. Nat., Notre Dame, 117: 177-191.

Menezes, N.A. 1970. Distribuição e origem da fauna de peixes de água doce das grandes bacias fluviais do Brasil. In: Comissão Interestadual da Bacia Paraná-Paraguai. Poluição e Psicultura. Faculdade de Saúde Pública da USP, Inst. Pesca, CPRN, S.A., São Paulo. p. 73-79.

Nelson, J. S. 1994. Fishes of the world. New York, John Wiley \& Sons. 600p.

Odum, E. P. 1988. Ecologia. Rio de Janeiro, Guanabara. 434p.

PaIva, M. P. 1978. A ictiofauna e as grandes represas brasileiras. Revta DAE, São Paulo, 38 (116): $49-56$.

PIANKA, E. R. 1994. Evolutionary Ecology. New York, HarperCollins. 486p. 
PofF, N. L. \& W ARD, J.V. 1990. The physical habitat template of lotic systems: recovery in the context of historical pattern of spatio-temporal heterogeneity. Environ. Manag., Dordrecht, 14: 629-646.

Resh, V. H.; B Rown, A.V. et al. 1988. The role of disturbance in stream ecology. J. N. Am. Benth. Soc.,Lawrence, 7: 433-455.

STRAHLER, A. N. 1964. Quantitative geomorphology in drainage basins and channel networks. Handbook of Applied Hydrology. New York, McGraw-Hill. 726 p.

WinTERHALDER, B. 1980. Environmental analysis in human evolution and adaptation research. Hum. Ecol., London, 8 (2): 135-170.

Recebido em 28.10.2000; aceito em 18.10.2000.

Iheringia, Sér. Zool., Porto Alegre, (90): 157-166, 25 de maio de 2001 